\title{
THE VERY MODEL OF A MODERN LAW SOCIETY
}

\author{
W. H. HURLBURT, Q.C.*
}

\begin{abstract}
At a time in which the nature of self-governing professions, particularly the legal profession, is the subject of considerable public and legislative concern, it is increasingly important that a decisive statement of the present situation be made. Mr. Hurlburt explains the organization and functions of the Alberta Law Society, and while mentioning possible areas for improvement, stresses that the present system is operating substantially to the benefit of the general public. Further, he concludes that the existing organization, judging from its past accomplishments, is best equipped to meet the challenges that will face the profession, and the society, in the coming years.
\end{abstract}

\section{INTRODUCTION}

Some public attention is being directed to those occupational groups which are organized by statute into professional corporations. ${ }^{1}$ There is very little published information relating to the corporations which regulate the legal profession. The primary purpose of this paper is to describe one of those corporations, The Law Society of Alberta, and its functions. A secondary purpose is to outline briefly some challenges which that corporation is likely to face in the future.

Each professional statute establishes a governing body with a discipline power, with some influence over admission of members, and with power to conduct the business and affairs of the corporation including the setting of admission fees and annual fees. In some cases, but not all, the statute allows only members of the corporation to engage in the occupation. There were found to be 24 Alberta statutes of this kind. ${ }^{2}$ In Ontario the corresponding number of statutes was found to be 22. Similar legislation is found in other provinces.

A report made by Hon. J. C. McRuer and published in $1968^{3}$ directed its attention to the professional corporations. That report made several recommendations for changes in the Ontario professional statutes, including uniformity of legislation, lay participation on the governing bodies, procedural protections for members and some restrictions on rule-making powers. Subsequently, the Law Society Act, $1970^{4}$ made a number of changes in the structure of the Law Society of Upper Canada. ${ }^{5}$ It did not provide for lay representation on the governing body as recommended in the McRuer Report, although it did provide that the Attorney-General would have a status as guardian of the public interest. ${ }^{6}$ It also provided for the creation of a "Law Council", " which is required

Barrister and Solicitor, of Hurlburt, Reynolds, Stevenson and Agrios, Edmonton, Alberta.

2 The words "profession" and "professional" refer here to those occupations and groups which are the object of statutes of the kind described in this paper. No attempt is made to relate these to the ordinary use of the words.

2 Acts Conferring Powers of Self.Government on a Profession or Occupation, a paper prepared for the Special Legislative Committee on Professions and Occupations by $G$. R. Bretten. The same researcher found an additional 62 occupations regulated by registration, certification or licensing requirements.

3 Report of Royal Commission, Inquiry into Civil Rights, 1968, Ontario.

- S.O. 1970, c. 19.

s See Arthurs, Authority, Accountability, and Democracy in the Government of the Ontario Legal Profession, (1971) 49 Can. Bar Rev. 1.

B S.O. 1970 , c. 19, s. 13(1).

7 Id. 8.26. 
to meet at least twice yearly and to "consider the manner in which members of the Society are discharging their obligations to the public and generally matters affecting the legal profession as a whole." It is composed of a large number of legal functionaries and nine members nominated by the Lieutenant-Governor-in-Council. It has been found somewhat unwieldy and ineffective. In November, 1972, the Law Society of Upper Canada announced that it would invite two lay members to sit with the Benchers of the Law Society. ${ }^{8}$

In Quebec, a Commission of Inquiry on Health and Social Welfare (sometimes called "the Castonguay-Nepveu Commission") was established to look into health and welfare matters. In the course of its inquiries it came to somewhat sweeping conclusions ${ }^{9}$ about professional organizations in Quebec, both inside and outside the health and welfare field. Its report also made recommendations relating to uniformity of legislation governing professional groups and public participation. In 1971, the Government introduced Bill 250 which would have intruded persons appointed by the Government at all stages of administration of professional groups. It would also have provided for uniformity and would have curtailed the powers of the professional orders. There followed a period of discussion between the Government and the Bar of Quebec. In September, 1972, the Government announced that it would propose amendments to Bill 250 which would to a considerable extent remove the threat to the independence of the practitioner.

In Manitoba, a special committee of the legislature was established to look into professional legislation. The committee has not yet reported.

In Alberta, the legislature at its 1970 session set up a Special Legislative Committee to review legislation pertaining to the regulation of professions and occupations and to examine the policies and principles underlying such legislation. The Committee reported progress at the 1971 session. ${ }^{10}$ Although the Committee ceased to exist when the legislature was dissolved for the election of that year, it was re-established at the spring session of 1972 and its report is likely to be made before this paper is published.

\section{FUNCTION OF THE LAW SOCIETY}

The right to counsel is a fundamental right. Every citizen must be able in time of need to find an adviser who will advise him about his legal rights and how to assert them. The citizen must be able to find an advocate who will put his case before any tribunal, no matter how difficult or unpopular that case may be. The citizen must be able to disclose everything to his adviser and advocate secure in the knowledge that what he has disclosed cannot be used against him. His right to advice and advocacy will otherwise be meaningless. A citizen without access to independent counsel is not a free citizen.

The lawyer must therefore be free to advise his client and to represent him, that is, the lawyer must be free from outside threats and

\footnotetext{
- Toronto Globe and Mail, November 21, 1972. The Law Society pointed out that it would require an amendment to allow them to vote.

9 The Profession and Society, Report of Commission of Inquiry on Health and Social Welfare, Part 5 (1970).

10 Report of the Special Committee established to conduct a Review of Legislation pertaining to the Regulation of Professions and Occupations, 1970-71.
} 
pressures, and from pressures from the Government of the day when his client's case is unpopular with that Government. On the other hand, the client must be assured that the lawyer's standard of conduct and competence is of the highest.

There is an apparent conflict between the client's need to have a lawyer who is free from outside pressures and the client's need to have a lawyer whose conduct is regulated by a strict code of ethics and who is required to have a high standard of training. A number of steps have been taken in order to resolve it. Lawyers are required to undergo extensive education and training. They are required as a condition of practice to be members of a statutory corporation (The Law Society of Alberta). They are required to use the powers of that corporation to regulate the conduct of its members. These requirements are intended to give assurance to the client that his lawyer is free from outside pressures and that the client's confidential information is protected from disclosure. They are also intended to give assurance to the client that the standards of training and conduct of the lawyer are regulated in the public interest.

The principal function of the Law Society, then, is to regulate the conduct of lawyers. It also plays a part in the training and education of lawyers, and performs certain other functions which require the organized direction of the legal profession and its resources. These other functions include such things as the provision of Legal Aid and the maintenance of a compulsory plan for insurance of lawyers against claims based on professional negligence.

I say at this point that in my opinion the function of the Law Society should extend to all matters relating to the provision of legal services to the community. It does not and should not claim any responsibility for other institutions involved in the making of law or in the administration of justice, or for the making or reform of the law generally. The legal profession should be active in these fields, but not through the Law Society. The Law Society should not invade fields of public policy outside those for which its powers are designed, and it should not exert compulsion upon its members save to the extent necessary to perform its proper function.

\section{DESCRIPTION OF THE LAW SOCIETY}

The Law Society of Alberta is a corporation created by statute and continued by the Legal Profession Act. ${ }^{11}$

Section 92 of the Act provides that no person but an active member of the Society shall practise or act as a "barrister" or as a "solicitor". These two words encompass the whole field of advising and acting in legal matters. Therefore, a person who wishes to practice law must become a member of the Law Society. He must also maintain himself on what is called the "active practising list". If he wishes to remain a member of the Society but does not wish to practise law he may have his name removed from the practising list and placed on a list of members who retain their status as members but are not entitled to practise.

The active practising list in July, 1972 included more than 1,500 members. Some 1,270 of these were lawyers in private practise. The list

" R.S.A. 1970, c. 203. 
also includes some academic lawyers, lawyers employed by Government and lawyers employed by business and industry. ${ }^{12}$

The lawyers on the active practising list elect, by secret ballot, ${ }^{13}$ a governing body of 17 members. ${ }^{14}$ The members of the governing body are called "benchers". ${ }^{15}$ The name is one which imports the traditions of the legal profession and emphasizes that lawyers across the country maintain those traditions. The benchers carry on the active business of the Society and exercise virtually all its powers. ${ }^{16}$

The Law Society presently maintains an office at Calgary; its office has over the years been either at Edmonton or Calgary. Its permanent staff include the Secretary, the Deputy Secretary and four other people in the Law Society Office. ${ }^{17}$

The operating budget of the Law Society for the fiscal year 1972-73 is $\$ 201,600.00 .{ }^{18}$ This does not include the contributions of its members to the Assurance Fund or to the group Errors and Omissions Insurance Plan which I will describe later. Each member on the active practising list pays an annual fee, currently $\$ 95.00$ for members practising in Calgary and Edmonton; $\$ 90.00$ for members practising in other centres with law libraries; and $\$ 85.00$ for members practising in other places. All members who handle trust money, other than Government employees, must pay an additional fee of $\$ 25.00$ per year to maintain the Assurance Fund. Members in private practice also must pay an additional $\$ 185.00$ for basic Errors and Omissions Insurance. The benchers fix these fees annually.

\section{SPECIFIC FUNCTIONS OF THE LAW SOCIETY}

\section{Education and Admission}

\section{(a) Requirements for admission to membership}

Anyone who has the educational requirements required by law, who is of good character and reputation and is a Canadian citizen or British subject, is by law entitled to apply for admission to the Law Society. It is commonly thought that professional bodies in Alberta control admission to membership. This opinion is quite wrong. The law, and not the Law Society, prescribes the qualifications for membership. It will be seen from what follows that the Law Society has a function in deciding whether some of those qualifications have been met but is more vulnerable to criticism on grounds of laxity than on grounds of restrictiveness. In fact, at the date of this paper no one, so far as is known, has been permanently refused admission on grounds which are under the control of the Law Society.

\section{(b) Academic education}

The prevailing opinion in Canada is that the best known training for the practice of law is a combination of academic education at the Uni-

12 Benchers of the Law Society of Alberta, Brief to the Special Legislative Committee on Professions and Occu. pations, August 1, 1972, at 3.

13 Legal Profession Act, R.S.A. 1970, c. 203, 8. 10(2).

14 Id. 8.10 and $8.12(3)$.

is Id. B. $5(1)$.

16 Id. s. 5(2).

17 Benchers, supra, n. 12 at 4.

18 Summary of the Proceeding of Meetings of the Benchers held at Calgary, Alberta on July 17th, 1972 and at Edmonton, Alberta, on October 26th, 27th and 28th, 1972. 
versity level and of practical or vocational training.

The Legal Profession Act prescribes two academic requirements. One is a degree in law from an Alberta University, or a degree granted elsewhere which is considered equivalent to an Alberta Bachelor of Laws Degree. ${ }^{19}$ The other is an earlier degree (e.g., Bachelor of Arts or Bachelor of Commerce) or two years leading towards an Alberta degree in Arts, or equivalent qualification obtained outside Alberta. ${ }^{20}$ The Universities Co-ordinating Council, an academic and administrative body representing the three universities in the Province, decides whether qualifications obtained outside Alberta are equivalent to those obtained in Alberta.

The University of Alberta is the body which effectively determines the content of academic legal education in the Province. It is at present the only University in Alberta with a faculty of law, though others may be created. The University grants the Bachelor of Laws Degree which, by law, must be recognized by the Law Society. The University determines what educational standards are required for admission to the study of law leading to the Bachelor of Laws Degree.

The Law Faculty Council, a body including some twenty members of the Faculty of Law, makes day-to-day decisions for the University Faculty of Law, and makes policy recommendations to the University. It also includes 3 undergraduate students and one graduate student, as well as one representative of the Law Society.

The Law Society of Alberta has less influence upon legal education than does any other provincial law society or equivalent professional organization in any other Province of Canada. Indeed, several of the other law societies have the power to prescribe legal education in their provinces.

\section{(c) Vocational training}

(1) Articles

The holder of a law degree is required to spend a year under "articles".21 This is a form of apprenticeship. The student enters into articles of agreement with a practising lawyer, whereby the principal undertakes to instruct the student and the student undertakes to receive instruction from the principal and to work with him. At the present time the usual wage is between $\$ 400.00$ and $\$ 500.00$ per month.

Service under articles is intended to ensure that the student acquires practical skills, ethical standards, and professional judgment. It does these things by requiring him to do legal work under the supervision of his principal and his principal's associates. It enables him to see how they and lawyers with whom they come into contact carry on the practice of law.

I believe that some form of vocational training is essential. It must supplement the academic training, because that training by itself cannot equip a lawyer to meet the practical problems which he must face. I believe also that service under articles is by far the best form of vocational training, and cannot see any satisfactory substitute for instruction and example under the actual conditions of practice.

\footnotetext{
19 Legal Profession Act, supra, n. 13 at 8. 39 (1) (c).

20 Id. $8.39(1)$ (b).

21 Legal Profession Act, supra, n. 13 at 8. 39 (2).
} 
The Law Society at the present time is faced with an extremely difficult problem by reason of a great increase in numbers of graduating students both in Alberta and across Canada. The Law Society has no control over the numbers of students admitted into the law faculties and graduated from them. It is determined to do its utmost to find places for students to spend their article year so that they may qualify for membership in the Law Society, and has so far been successful in finding places. Many practising lawyers have made places available to students through a sense of duty and against their own financial interest. The graduating classes from the Faculty of Law in The University of Alberta have grown from 50 in 1967 to 123 in 1972 . It is expected that the graduating class of 1974 will be 170.22

The numbers of law school graduates are increasing all across the country. An Ontario Committee in October, 1972 made a report ${ }^{23}$ to the Law Society of Upper Canada in which, among other things, it recommended abolition of service under articles. Reliance would be placed on the extensive Bar Admission Course of the Law Society of Upper Canada. This is not the place to discuss that recommendation or its applicability to provinces without an equally ambitious Bar Admission Course.

\section{(2) Bar admission course}

In order to ensure that lawyers are familiar with certain basic practical material, the Law Society established a Bar Admission Course. The course involves extensive work assignments to be done by students in the offices where they spend their time under articles. It also involves 10 days spent in lectures or seminars during the year under articles.

At the conclusion of the Bar Admission Course, the Law Society sets an examination, by agreement with the Universities Co-ordinating Council, which has the power to supervise the examination. Experience indicates that anyone who has the capacity to obtain a Bachelor of Laws degree has the capacity to pass the Bar Admission examination. No one has been prevented from entering the practice of law by reason of failure to pass the Bar Admission examination or its predecessors.

The situation varies from province to province, and some provinces have no bar admission course at all. The Ontario course, which is the most extensive, involves an additional six months of classroom instruction in practical subjects following the completion of the year under articles. For various reasons, including the burden upon the students themselves, as well as the burden upon the profession, I do not believe that such an extensive bar admission course is warranted in Alberta at this time.

\section{(d) Character}

The Legal Profession Act requires the Education Committee of the Law Society to satisfy itself that a person who applies to be admitted to membership is "of good character and reputation." 24 In the past the Law

\footnotetext{
22 Benchers, supra, n. 12 at 9.

23 Report of the Special Committee on Legal Education, 1972. The Law Society of Upper Canada, Osgoode Hall. See also Report of the Special Committee of the Conference of Governing Bodies of the Legal Profession in Canada on Admissions and Articling. February 26th, 1972, which made reference to the possibility of a "conditional call" as an alternative to articles, and Report of the Committee on Legal Education, Cmmd. 4595, March, 1971 ("The Ormrod Committee").

24 Legal Profession Act, supra, n. 13 at 88. 39, 40, 41, 42, 45.
} 
Society has in most cases accepted two reliable references as sufficient evidence of good character and reputation. ${ }^{25}$ It has considered that the risks involved in maintaining open admission to membership were justified.

The Law Society recognizes, however, that a lawyer occupies a position of trust and that the public interest requires the exclusion of unsuitable persons, such as those with a criminal background. The Law Society now requires persons applying for admission as students-at-law to disclose any criminal convictions and bankruptcy proceedings, a step thought necessary because of the great numbers of students in the law schools, and since the personal knowledge of the individual which existed previously is no longer available.

These additional requirements are beginning to disclose occasional problems. The Law Society's policy should be to try to avoid the evil of a closed profession on the one hand and the evil of corrupt entrants into the profession on the other. It should screen the character of the applicants only to the extent which it considers necessary to protect the public. It should also continue to regulate the conduct of students-at-law and lawyers through its discipline power.

\section{(e) Citizenship status}

The Legal Profession Act requires that anyone who is to become a member of the Law Society must be a Canadian citizen or British subject. ${ }^{26}$

The situation varies somewhat from province to province. The usual requirement is Canadian citizenship, or alternatively either Canadian citizenship or the status of British subject.

I believe that all lawyers should be Canadian citizens. Our legal institutions are vital to our national life and those involved in them should give at least this much evidence of commitment to that life; but I believe that it should be possible for one who is not a Canadian citizen to obtain temporary membership in the Law Society while he goes through the procedures necessary to become a Canadian citizen.

\section{(f) Lawyers from outside Alberta}

Lawyers who have practised in Canada for three out of the last five years can become members of the Law Society of Alberta and can transfer to Alberta to practise. ${ }^{27}$ Lawyers who have not practised for the three years can come in as articled students. ${ }^{28}$ The Education Committee of the Law Society usually sets the term which the lawyer must spend under articles at substantially less than the full year which students who are not qualified lawyers must spend.

Lawyers from the United Kingdom (with some exceptions), New Zealand, Australia and Eire who have had three years' practice in the preceding five years can come into Alberta as articled students and can be admitted to the practice of law upon completing their period under articles and taking the Bar Admission Course and examination. ${ }^{29}$ The

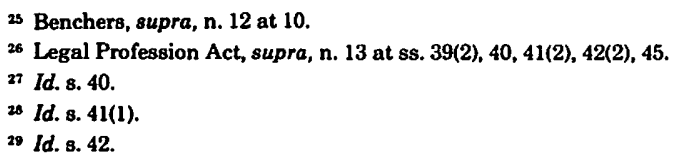


Law Society may waive these strict requirements for an English solicitor employed by the Attorney-General's Department. ${ }^{30}$

\section{(g) Appeals}

In the past, the Legal Profession Act did not give any recourse to a person who was refused admission to the Law Society. The benchers recommended that the Legal Profession Act be amended to allow a rejected applicant to appeal the decision of the Law Society to the Appellate Division of the Supreme Court of Alberta and this was done at the 1972 fall session of the legislature..$^{31}$

\section{Discipline $e^{32}$}

\section{(a) In general}

Subject to the control of the courts, the benchers of the Law Society have power to "discipline" a member who is "guilty of conduct unbecoming a barrister and solicitor." That is to say, they have the power to make the finding of guilty, and the power to impose a sanction or penalty. They may reprimand the member and may fine him up to $\$ 1,000.00$ for each offence. They may order that he be suspended from practice for a stated period of time, or that his name be struck from the roll, i.e., that he be expelled from membership in the Law Society and therefore be unable to practise law. In addition to any of these penalties, they may order the member to pay the costs of the Law Society's investigation in an amount fixed by them.

The Law Society investigates every complaint made against a lawyer, as well as all information which indicates the need for investigation. The investigation may vary from obtaining a simple explanation from the lawyer to carrying out a very involved and complicated examination of files and witnesses. A bencher member of the Discipline Committee considers every complaint.

In the $15 \frac{1}{2}$ years ending in July, 1972, the Law Society of Alberta conducted 101 formal investigations. The benchers struck 29 members from the rolls; suspended 4 members; fined 27 members and reprimanded 38 others. (In some of these cases more than one penalty was imposed).

The Deputy Secretary of the Law Society spends the greatest part of his time on discipline matters and a very substantial part of the cost of operating the Society's office is attributable to them. A significant part of the time of the benchers is also spent on discipline matters. In each of the 5 years ending in October, 1971, the average actual out-of-pocket expense for transcripts, and expenses of investigating committee was $\$ 5,381.00$, of which, on the average, $\$ 1,450.00$ was recovered as costs from members who were found guilty. In addition, the Law Society spends substantial amounts on "spot audits" which are really part of the discipline process. In $1970-71$ the amount spent was $\$ 17,426.00$.

\section{(b) Procedure}

The procedure followed by the Law Society in discipline matters is as follows:

\footnotetext{
30 Id. s. 42(1.1) which was added by S.A. 1972, c. 59, s. 2.

31 S.A. 1972, c. 114, s. 4.

32 See Legal Profession Act, supra, n. 13 at Part 3, ss. 47 to 75, and Benchers, supra, n. 12 at 12-18.
} 
(1) A discipline matter is initiated either by a complaint about a lawyer's conduct, or by the Society coming into possession of information which suggests the possibility that a lawyer's conduct may have been improper.

(2) The Secretary of the Law Society, or the Deputy Secretary, asks the lawyer for an explanation. In some cases he will make other inquiries.

(3) The Secretary or Deputy Secretary refers the file to a bencher who is a member of the discipline committee of the Law Society. The discipline committee member may ask for further information and inquiries. Occasionally he may arrange to have some person appointed to be an official investigator to examine the lawyer's records or make other investigations.

(4) The discipline committee member may decide that there has been nothing improper in the lawyer's conduct. In that case he will direct that the matter be closed. The complainant may appeal that decision to the benchers as a whole.

Clients often complain about real or apparent inaction by the lawyer, or about the lawyer's failure to keep them fully informed. The discipline committee member may resolve these complaints by seeing that the lawyer finishes the job with dispatch or reports to the client. The discipline committee member in such a case may also informally point out to the lawyer the desirability of being more prompt or more communicative in the future.

If the discipline committee member is of the opinion that the lawyer's conduct is sufficiently below standard to require further action, he will direct that an investigating committee be constituted and that a formal investigation be held.

(5) An investigating committee is a committee of three benchers appointed for the particular case. The committee holds a hearing in the form of a trial. It gives notice to the lawyer involved, who is entitled to appear before the committee with or without counsel and to present his own case and to cross-examine witnesses who give evidence at the hearing. The committee usually gives notice to the complainant, if there is one, and hears the complainant's evidence. The hearing is not open to the public but a court reporter attends and, if necessary, prepares a transcript of the hearing. The rules of evidence do not apply to the investigating committee. The lawyer is subject to being required to appear and answer questions under oath even if the answers tend to incriminate him; he is, however, entitled to a fair hearing of a judicial nature.

(6) At the conclusion of the hearing the investigating committee may decide to dispose of the matter on the spot, but it may do so only by a unanimous decision.

(7) When the investigating committee disposes of the matter it may either dismiss the charge if it finds that the lawyer has not been guilty of conduct unbecoming a barrister and solicitor; or find the lawyer guilty, and reprimand him with or without a fine of up to $\$ 300.00$ for each offence, and assess the costs against him.

The chairman of the discipline committee may appeal the investigating committee's decision to the benchers and will do so if he thinks it too lenient. The lawyer may appeal if he considers it too harsh.

(8) If the investigating committee does not dispose of the matter on the spot, the transcript of evidence and the committee's report as to the facts are sent to the benchers and to the lawyer involved. The benchers 
then meet to consider the matter and the lawyer is entitled to appear by himself or with counsel. The benchers then decide whether or not the lawyer is guilty of conduct unbecoming a barrister and solicitor. If they find him not guilty they dismiss the charge. If they find him guilty they impose a penalty.

\section{(c) Appeal}

The Legal Profession Act allows a lawyer to appeal to the Appellate Division of the Supreme Court of Alberta against a decision of the benchers. Therefore a lawyer who is disciplined is entitled to seek the protection of the courts. Some have done so. I believe that the right of appeal constitutes a proper and sufficient safeguard for the rights of the individual lawyer.

Before 1966 a lawyer could appeal only from a suspension or disbarment, but could not appeal at all if the benchers were unanimous. The Benchers took the initiative to have the present appeal provision included in the 1966 Act, believing that lawyers should have the protection of the courts.

\section{(d) Other provinces}

The pattern of discipline powers and procedures is generally the same in the smaller provinces. As the affairs of the particular society become more complex, it becomes necessary to have more of the discipline function performed by committees of the governing body and less by the governing body itself. In Quebec the governing body as such does not deal directly with individual discipline matters, which are handled by committees from whom appeals go to appeal tribunals.

\section{Standards of Conduct}

The benchers are empowered to decide whether or not a lawyer has been guilty of conduct unbecoming a barrister and solicitor. That power involves the power to determine what is unbecoming conduct. The benchers therefore effectively have the power to describe standards of conduct for lawyers and have traditionally exercised this power.

The Law Society for many years distributed to its members canons of legal ethics, and now distributes a "Professional Conduct Handbook". This handbook does not constitute a complete code of ethics, but rather consists of concrete rulings which the benchers have found necessary by reason of specific problems coming to their attention. The benchers have thus far thought it better to allow the rules of ethics to be worked out in the same way as the common law itself, by decisions made from time to time on specific facts. Lawyers are well acquainted with the longstanding traditions of the bar and with the ethical standards of the bar. There are textbooks and publications on the subject which are available. The law societies will, before long, have available to them the results of a massive study of legal ethics which the Canadian Bar Association has been engaged in for some years.

\section{Fees ${ }^{33}$}

Every lawyer's account in Alberta can be taxed by the Clerk of the Court, with a right of appeal to the court. The Probate tariff is established 
by Order-in-Council. In Legal Aid matters the tariff is established by negotiation between the Law Society and the Government. The Law Society does not have the power to set scales of fees which must be paid by the client.

The Law Society does, however, issue a guide ${ }^{34}$ as to the fees which should be charged for certain types of service which lend themselves to classification, for example, real estate transactions and the formation of private companies. This is not a minimum tariff nor is it a mandatory guide. It is a recommended guide. The Law Society does not enforce adherence to it. Within the memory of those associated with the Law Society, no lawyer has been charged with accepting a fee which is below that suggested by the Law Society's tariff. Indeed, many lawyers do not adhere to the tariff, and local bar associations have put out different suggested schedules.

\section{Assurance Fund}

Since 1939 the Law Society has maintained an Assurance Fund to protect clients against all defalcations by lawyers. Since that date the Law Society has made good all defalcations.

The Law Society was a pioneer in the field. Its Assurance Fund was the first in Canada and probably in North America. It has never required that the claimant pursue difficult legal procedures in order to obtain compensation.

Up to October 31st, 1971, the Law Society had paid out of the Assurance Fund a total of $\$ 244,846.53$. The assets of the Fund at that date, valued at cost, were $\$ 732,659.00$. The Fund is entirely built up from contributions by the lawyers of Alberta and the income earned by those contributions.

The Rules of the Law Society have always required lawyers to maintain clients' money separately from their own. The Law Society requires each lawyer to file an annual certificate from an independent auditor, usually a chartered accountant. The auditor must now report to the Law Society whether or not the lawyer has maintained separate funds for his trust money; whether or not the lawyer has reconciled his trust account quarterly during his fiscal year; whether or not the lawyer has compared his trust ledger balances with the reconciled trust account balance quarterly; whether or not any discrepancies discovered have been promptly rectified; whether or not the auditor has independently verified the balances; and whether or not the lawyer's trust account was in balance at the time of the audit. The auditor must also ask the lawyer about any cases in which individual accounts in the trust account had become overdrawn in excess of $\$ 10.00$ at any time during the year. The discipline committee follows up all discrepancies which the auditors' reports disclose.

minimum prices of services (s. 16), presumably including professional services, except arrangements exempted by Provincial Statute and regulated on a continuing basis by a board, commission or other public body appointed pursuant to the provincial legislation and charged with the duty of protecting the public interest (8. 92). This appears to be intended to give effect to the recommendation of the Economic Council of Canada that fees for self-employed professionals be subject to competition policy (Economic Council of Canada, Interim Report on Competition, July, 1969). It is not clear whether a guide such as that referred to below would have been affected by Bill C-256 or whether such a guide will be affected by any legislation which may be enacted to cover the ground which was to be covered by Bill C-256.

34 Tariff of fees approved as a guide to the members of the Law Society of Alberta by the benchers of the Society on January 20th, 1972. 
In addition the Law Society has developed a system of "spot audits". The Law Society's auditors without advance warning examine the trust records of all practising lawyers. In the 1970-71 fiscal year the auditors conducted 157 spot audits of individuals or firms. There were then 399 individuals or firms practising in the Province.

These measures taken by the Law Society under its statutory powers have greatly improved the keeping of accounts by lawyers over the past ten or fifteen years. They are an important protection to the public. The individual lawyer and the Law Society bear the expense. The Law Society of Alberta has led the way in setting up and maintaining these important controls and I believe that it is still the leader in the field.

\section{Compulsory Errors and Omissions Insurance}

The Law Society requires every lawyer in the private practice of law to be insured for at least $\$ 100,000.00$ against claims by clients for errors and omissions by the lawyer. This requirement is in the interest of the profession because it enables each practising lawyer to obtain insurance. It is also very much in the public interest because it ensures that lawyers can pay judgments obtained against them in actions based on professional negligence and it provides a machinery for settlement of claims. To the Assurance Fund protection against defalcations, it adds insurance protection against negligence and carelessness. The Law Society of Alberta was by a narrow margin the first to have such a plan in Canada, and it was probably the first in North America.

\section{Legal Aid}

The Law Society, under agreement with the Attorney-General, administers criminal and civil legal aid throughout the Province.

The legal profession has traditionally given much of its time and skill for the benefit of those who cannot pay. In the 1930's Alberta adopted the "Needy Litigant" procedure ${ }^{35}$ which operated on the civil side, and was, in its time, an enlightened scheme. Under it persons who could not pay for legal services could obtain free legal services in civil matters. The Government contributed to the scheme by waiving all court fees. Lawyers provided free services and, without compensation, administered the scheme. With the increasing complexity of society and life in Alberta in the late 1950's and 1960's, the strain on this system became intolerable.

On the criminal side, apart from free services provided by the legal profession, there was until 1964 very little assistance for those who could not pay for legal services. The Court would sometimes appoint a lawyer to represent the accused in very serious criminal matters and the Attorney-General's Department would pay a fee to the lawyer. There was, however, no general legal aid plan.

In 1964 the Government was concerned about the lack of systematic legal aid in criminal matters. The Law Society and the Government agreed to set up a pilot project at Edmonton. Lawyers provided legal services at reduced rates, and free interviewing services which were an important part of the plan. Later the plan was gradually expanded throughout the Province, and by 1969 the budget had reached approximately $\$ 250,000.00$. This was all done by informal arrangements between the Law Society and the Government.

3s O.C. 464/32. Rules of the Supreme Court of Alberta, 1944, Rules 679-711. Alberta Rules of Court, 1969, Rules 931-863, (struck out following introduction of Alberta Legal Aid Plan by Alta. Reg. 19/71). 
In 1966 the Law Society became concerned about the strain on, and the limited scope of, the Needy Litigant programme. Law Society committees began to study the question of civil legal aid and to develop ideas. By this time the pressures on Government funds had increased, and it was not until 1968 that the Law Society was able to obtain Government approval of a pilot project to be conducted at Edmonton. This project was initially financed by a grant of $\$ 25,000.00$ from the AttorneyGeneral's Department.

In 1969 the Law Society asked a Committee headed by Mr. Justice S. S. Lieberman to look into the whole matter of legal aid, civil and criminal. The benchers approved the Committee's report ${ }^{36}$ and made it the basis of a proposal to the Government. The proposal called for the establishment of a complete civil and criminal legal aid plan for the Province. The Government accepted the proposal and in 1970 the Legislature amended The Legal Profession Act ${ }^{37}$ to allow the Attorney-General and the Law Society to enter into an agreement to provide a legal aid plan. The plan was originally funded in the amount of $\$ 700,000.00$, including administration expenses, for the 1970-71 fiscal year. For the $1972-73$ fiscal year the budget is $\$ 900,000.00$.

The Alberta Legal Aid Plan now provides assistance to all qualified accused persons in all serious criminal matters. The Plan also provides assistance to qualified persons in civil matters if approved by the Legal Aid Committee. ${ }^{38}$

The Law Society is responsible for administration of the Plan. It works through a Joint Legal Aid Committee appointed in part by the Law Society and in part by the Attorney-General. One Law Society appointee is not a lawyer. The Joint Legal Aid Committee is assisted by a director resident in Edmonton and a deputy director resident in Calgary. Below the Joint Legal Aid Committee there are area committees in various parts of the Province composed of lawyers and some members of the public.

The Law Society's part in the administration has been voluntary and without cost to the Plan, and lawyers have carried on the interviewing of accused persons without charge. These services amount to a very considerable contribution over the years and have made the Plan possible. The scale of fees paid to lawyers who provide legal services under the Plan is deliberately kept below that which would normally be earned for such services.

The Alberta Legal Aid Plan is second in Canada only to that of Ontario in its scope and scale. The total cost of the Plan in Alberta is something in excess of sixty cents per capita as compared to approximately $\$ 1.50$ per capita for the Ontario Plan.

The Alberta Legal Aid Plan must continue to improve. Administrative problems still exist, though they are being overcome, and financial limitations will not permit the Plan to offer all the services which it should offer. I believe, however, that the Plan is an example of how the self-governing legal profession, the Government and the Legislature can work together to serve the highest public interest. The

\footnotetext{
36 Report and Recommendations by the Joint Committee operating the Edmonton pilot project, January 5th, 1970.

37 S.A. 1970, c. 65, 8. 2, now Legal Profession Act, supra, n. 13 at 8. 4.

ss Benchers, supra, n. 12 at 23-25.
} 
intervention of the Federal Government in legal aid will provide new opportunities and new challenges.

\section{Law Reform}

Over the years the benchers of the Law Society have made many suggestions for law reform, sometimes on their own initiative and sometimes at the request of the Government. In 1964 they decided that they should make institutional provision for the law reform function and established a Law Reform Committee composed of benchers, judges, practising lawyers, academic lawyers and government lawyers. This Committee did useful work, but it came to the conclusion that without funds and without staff its activities must necessarily be severly limited.

In these circumstances, the benchers conceived of a proposal for a permanent law reform body as a joint venture of the University of Alberta, the Law Society, and the Government acting through the Attorney-General. ${ }^{39}$ They proposed the establishment of such a body to the University and to the Attorney-General. The body was established at the beginning of 1968 and is the Institute of Law Research and Reform.

The work of the Institute is done by a Board of Directors, which is made up of a permanent Director, who is chosen by the Board, one representative from each of the three constituent bodies, an additional three members co-opted by the first four and a representative of the University administration. A member of the Appellate Division of the Supreme Court acts as a judicial adviser. The University and the Government provide the funds for the Institute, and the University provides office space and the use of various facilities.

The benchers continue to take an interest in the Institute and support it. Two benchers are actively engaged in the Institute's work, along with two other practitioners.

I believe that the most appropriate vehicle for the energy of the legal profession as a whole, in the fields of law research and reform, is a voluntary organization with a broad base of support and participation. The Alberta branch of the Canadian Bar Association has been active in these fields. If it is able to maintain a position as the voice of the profession in these fields, it is, in my opinion, more appropriate that it do so than that the Law Society should function in fields where it has no mandate.

\section{THE CHALLENGE OF THE FUTURE}

I have to this point described only the workings of the Law Society of Alberta, the statutory corporation. I have not described the way in which the profession itself functions. I propose, however, to assume for the purposes of this paper that it would be better if legal services could be made available more swiftly, more cheaply, and to more people. I believe that this assumption is correct, and that it gives rise to a challenge to the legal profession which can be met effectively only through the use of the machinery of the Law Society.

I will break the discussion down into a number of parts.

39 Agreement dated August 30th, 1971 between Her Majesty the Queen in right of the Province of Alberta as represented by the Attorney-General, the Board of Governors of the University of Alberta, and the Law Society of Alberta, replacing Agreement among the same parties dated November 15th, 1967 as amended by Agreement, dated December 18t, 1969. 


\section{Provision of Legal Services to Those Without Funds}

The Alberta Legal Aid Plan has been an important step in the provision of legal services to those who cannot pay. On the criminal side, however, the plan assists only those who face criminal charges of a certain gravity. On the civil side it is restricted in fact to those who recognize that they have a legal problem and are able to find a lawyer or the legal aid office. The trend towards "storefront" or "community" legal services, and the experience resulting from them, appear to indicate that there is a need which is not met by the Legal Aid Plan. I believe that there should be a continuing study of the need, and that the Law Society should be involved in providing the initiative for the necessary study and for the necessary corrective steps.

\section{Legal Services for People of Moderate Means}

There are important groups in the population who do not qualify for legal aid but for whom the cost of legal services is inhibiting or prohibitive. I believe that the legal profession should be giving thought to means of providing legal services to these groups. In particular, there are two possibilities which I think should be investigated:

\section{(a) Group legal services}

I believe that ways should be found to allow automobile clubs, trade unions, and other groups to arrange for specific kinds of legal service at a cost which will reflect the advantages of volume of work and certainty of payment. Such arrangements may well involve some modification of the profession's traditional attitudes towards advertising and touting, while preserving the substance of the values reflected in the present rules.

\section{(b) Prepaid legal plans}

There are great difficulties in plans which spread the cost of legal services. It may be that insurance principles will not cover protection against needs which depend to a great extent upon the volition of the persons protected. However, I believe that it should be possible to find some means of spreading the cost over a group and that it should be possible to devise proper safeguards.

\section{Cost of Legal Services}

The cost of legal services, of course, affects the availability of legal services to the two classes which I have already discussed. It is, however, a problem which should be considered separately. It is possible that the increasing numbers of entrants into the profession may, by pressure of competition, bring about a significant reduction in the cost of legal services, but that remains to be seen. Apart from the part of the cost which constitutes the lawyers' own incomes, however, I believe that the profession should be considering the form of organization of the private law office, the practicability of performance of various components of legal services by persons other than lawyers and matters of that kind. In the absence of initiatives from other legal organizations and from individual practitioners, I think that the initiative must come from the Law Society.

\section{Promptness of Delivery of Legal Services}

The greatest complaint about legal services is delay. Many processes necessarily involve delay, and the lawyer is unfairly blamed. But lawyers 
do contribute to the problem of delay. It may be that increasingly numbers will reduce individual workloads and that competition will result in improved service. I believe, however, that it is in this area that the way in which the discipline process operates is most open to challenge, and that the Law Society will have to use more effective means of control.

\section{Quality of Legal Services}

At present, the entrant into the profession must have certain academic qualifications and vocational training. Thereafter he need not give any evidence of competence nor take any further training. The Law Society does not supervise the competence of its members and it may have no legal power to do so; its continuing legal education programs reach only those who recognize that they need to keep up to date. I believe that the Law Society will have to devise some means, whether by compulsory continuing training or otherwise, of ensuring the competence of its members.

\section{Accreditation of Specialists}

Specialization exists among lawyers. Every lawyer does some things and not others. The question for the Law Society is whether specialization should be encouraged, and whether some means of accreditation should be adopted. While I personally view any such system with distaste, I believe that the public interest requires that some form of accreditation be adopted. I believe that the public should be given some means of recognizing those who are more likely to be competent in specific fields of law. I believe also that the requirements of continuing training and experience in the field should improve the competence of members. I would hope also that the fact of specialization will tend to reduce the cost of legal services, though I think that the evidence in favour of this proposition is far from conclusive.

A Committee of the Law Society of Alberta in October of 1972 recommended that the Law Society should commence discussions immediately with the other governing bodies of the legal profession to institute a program of specialist certification. ${ }^{40}$ The benchers of the Law Society expressed approval in principle of the recommendations, but recognize problems arising from limited resources and from the need for transferability from province to province on the one hand and the different conditions in different parts of the country, on the other.

The Law Society of Upper Canada on November 17th, 1972 approved in principle a proposal made by a Special Committee on Specialization in the Practice of Law. ${ }^{41}$ The recommendations reflect an active but cautious approach with two or three areas of specialization to be provided for at the outset. Practice in a specialized field would not be restricted to specialists. Specialists would not be restricted to practice in their fields of specialization.

The profession is, therefore, in the first stage of dealing with the question of specialization. I do not believe that it can provide a satisfactory answer unless the Law Societies of the Provinces act together.

\footnotetext{
co Specialist Certification in the Legal Profession, a report by a Committee consisting of J. H. Laycraft, Q.C. (Chairman) and G. A. C. Steer, Q.C., Carole M. Smallwood and R. D. Ross, Members.

"Communique, a brief informal report of the proceedings of the Benchers of the Law Society of Upper Canada in Convocation, November 17th, 1972.
} 


\section{The Legal System}

The responsibility of the Law Society to the public is in the field of legal services. It has no mandate from the Legislature or from its members to interfere in, or to reform, the operation of other institutions involved in the administration of justice, or to engage in the general reform of the law or the legal system. ${ }^{42}$

The legal profession, as distinguished from the Law Society, does have a responsibility to see that initiatives are provided for the continued examination of the legal system and for its reform where reform is necessary or desirable. If, as has sometimes been the case in the past, there is no organization of lawyers performing this function, the Law Society must, by default, perform it. The more effective and appropriate vehicle for the energies of the legal profession, however, is a separate and voluntary organization such as the Alberta branch of the Canadian Bar Association.

I believe, however, that there is another function which the Law Society should perform. Law and the legal system are too much of a mystery to the public. Too many people do not know their basic rights or how to obtain dependable information about them. The Law Society should in my opinion see that such information is made available and is disseminated as widely as possible. It should also disseminate information to the public about the way in which the legal system functions.

\section{CONCLUSION}

I believe that the Law Society is an institution which functions in the public interest. I believe that the description of its activities which I have given shows an impressive range of accomplishment.

I believe also, however, that it is the duty and the interest of the legal profession to accept the challenge of the times; to see that legal services are available to all; that legal services are provided expeditiously and at an acceptable cost; and that they are of a high quality. I believe that the Law Society has an important function to perform in the profession's answer to the challenge. The favoured position of the profession in society imposes the highest of duties to society. The professed ethical standards of the profession also impose that duty. The self-interest of the profession dictates the performance of that duty.

A recital of past accomplishments will not be a satisfactory substitute for future performance.

12 Upon occasion the Law Society can and should act as spokesman for its members in connection with particular problems, but this does not detract from the general statement made above. 